\title{
BORMARKETING, BORFOGYASZTÁS ÉS BORTERMELÉS HAZÁNKBAN
}<smiles>C[123I]</smiles>

\section{WINEMARKETING, WINE CONSUMPTION AND WINE PRODUCTION IN HUNGARY}

\author{
- \\ TÖRÖKNÉ KISS, Klára Ágnes

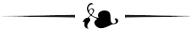 \\ Debreceni Egyetem, Kerpely Kálmán Doktori Iskola \\ (University of Debrecen, Kerpely Kálmán Doctoral School) \\ H-4032 Debrecen, Böszörményi út 138 . \\ e-mail: kiss.klara@agr.unideb.hu
}

The wine is still in Hungary in Hungarian history, culture, and one of the key elements of the economy are considered . Last, but not to the point of producing and selling the wine regions of livelihoods. Thousands of years in wine-producing traditions preserved in the modern winemakers, wine competitions demonstrate their skills.

KULCSSZAVAK: : bor, bormarketing, borfogyasztás, borkultúra, bortermelés
KEYWORDS: wine, wine marketing, wine comsuption, culture of wine, wine production

\section{BEVEZETÉS - INTRODUCTION}

\subsection{Bormarketing - Wine Marketing}

A marketing szakma eredetét az 1900-as évekre tehetjük és azóta egyre csak fejlődik. A marketing az egyik olyan gazdasági kifejezés, amire nincs egységes definíció. A marketing a társadalomtudományok kombinációja, mivel egyszerre fedi le a közgazdaságtan, pszichológia, a szociológia, az antropológia, a vezetéstudomány és az alkalmazott matematika különböző területeit. Szűkebb értelemben a marketing egy olyan vállalati tevékenység, ami a vevők, vagy felhasználók igényeinek kielégítése érdekében elemzi a piacot, meghatározza az eladni kívánt termékeket és szolgáltatásokat, megismerteti azokat a fogyasztókkal, kialakítja az árakat, megszervezi az értékesítést és befolyásolja a vásárlókat. Bizonyos értelemben a fogyasztói igényt is befolyásolja, új termékek bevezetésével. Tágabb értelemben a marketing a vállalat egészére kiterjedő filozófia, szemléletmód, amelynek megvalósítása a vállalati felső vezetés feladata, oly módon, hogy a vállalati résztevékenységek integrációjában a marketing szempontok domináljanak. A marketing, mint leíró tudomány olyan szervezeti funkció és eljárás, amely a vásárlók számára értéket teremt, kommunikál és közvetít, valamint az ügyfélkapcsolatokat olyan módon ápolja, hogy azok a szervezet és az érdekelt személyek számára egyaránt hasznot hajtsanak [5].

A bormarketing a marketing- és a bortudományok ötvözete, ahol szükség van a marketing módszerek, szemléletek, koncepciók ismeretére, és nem nélkülözheti a borászati alapismereteket sem [2]. A borászattal és forgalmazással foglalkozó vállalkozások piaci környezethez való alkalmazkodásának cél és eszköz-rendszerét jelenti [6]. A bormarketing szerepe a régi KGST piacok összeomlásával és a termékorientált szemlélet megszűnésével előtérbe került. Manapság a kereskedelmi tevékenységet a fogyasztók határozzák meg, a marketing szerepe ebben az ágazatban is felértékelődött, a borral szemben új elvárások jelentek meg.

A bormarketing témakörének főbb területei:

- Termék, áruk, szolgáltatások és elképzelések

- Szükségletek, igények és kereslet

- Csere, ügyletek, piaci szereplők, a köztük lévő kapcsolatok és viszonyok (erő, bizalom, konfliktus, közös érték)

- Teljesítménymutatók (költség, nyereség, érték, elégedettség stb.)

- Marketing-mix elemei [6].

A jó marketinghez az úgynevezett marketing mix / $4 \mathrm{P}$ : Product (termék), Price (ár), Place (elosztás), Promotion (ösztönzés)/ elemeinek átfogó alkalmazása szükséges. 
A pénz mellett, fontos a hatékony kommunikáció és az összefogás is. A címkén túl a bor reklámozására használható felületek tárháza szinte kimeríthetetlen, de nem elsősorban azért nem meríthető ki, mert valóban nagyon széles spektrumú, hanem mert nehéz a termék méretét a reklám méretével és költségével arányba hozni. Borok esetében - túl a címkén - a leggyakrabban reklám célokra használt közeg a webes felület. Egyre több borászat, pincészet él ügyesen ezzel a lehetőséggel, naprakész és hasznos információkat közöl weboldalán, illetve hírlevél formájában, azonban még mindig nagy azoknak a száma, amelyek a frissítésekre nem szánnak kellő figyelmet. Szép számmal akadnak azonban olyan személyes hangnemben megszólaló oldalak is, ahol arról is tájékozódhatunk, hol tart éppen a szüret, milyen munkák, telepítések folynak a szőlőben, illetve mi foglalkoztatja éppen a borászt. A borreklámok hatása tehát - bármilyen felületen is jelenjenek meg - ránk, borfogyasztókra mindig más és más, tekintve, hogy mi magunk is mások és mások vagyunk. A kiváló termőhelyi adottságok egyedül nem elegendőek a piacképes termék kialakításához. Ennek eléréséhez egy jó stratégiát kell kidolgozni, amelyre a termelők illetve pincészetek alapozhatnák a marketingtevékenységüket. Magyarországon a bormarketing jelentősége folyamatosan növekszik. Egyre több borpiaci szereplő ismeri fel azt a tényt, hogy a marketingszemlélet és a marketingeszközök megfelelő alkalmazása nélkülözhetetlen a tartós piaci siker eléréséhez a borászatban [4].

\subsection{Magyar borvidékek szerepe a marketingben - Hungarian Wine Regions in Marketing Roles}

A magyar borvidékek jelentős részét azokról a hegyekről nevezték el, amelyek lábánál találhatóak, mint például a tokaj-hegyaljai, a badacsonyi, a mecsekaljai. A származáshelyi-megjelölésnek a borok esetében nagyobb marketingereje van, mint a többi élelmiszeripari termékek esetében. Ahhoz, hogy egy termelő földrajzi eredet megjelölést használhasson, szigorú minőségi követelményeknek kell, hogy megfeleljen [2]. Magyarországon az elmúlt években a borvidékek számának növekedése mellett a szőlőterületek nagysága jelentősen zsugorodott. Míg 1986-ban tizenhat borvidéken 130 ooo hektáron, addig napjainkban huszonkettő borvidéken (legismertebb a Tokaj és Eger), nagyjából 83 ooo hektáron folyik a szőlőtermelés.

A magyar borászat történetében új korszak kezdődött az 1990 és 1994 között végbement privatizációval. Igaz, a magánosítás sok tekintetben vitatható volt, a volt tulajdonosok érdekeit, a földtulajdonlás használati és szakmai feltételeit sokszor figyelmen kívül hagyták, de kialakultak a családi szőlőbirtokok és a valódi pinceszövetkezetek alapjai. A magyar bortermelők mindig képesek voltak helyreállítani a jó minőségű bortermelés alapjait, visszaszerezve boraik nemzetközi jó hírét [7]. 2014-ben azonban jelentősen nőtt a borágazat támogatása, mivel a borpiac több pénzt kap az Magyar Államtól. Az ezt megelőző borpiaci évben (2012/13) a borpiac állami támogatottsága 6,5 milliárd forint volt majd ezt követően jelenleg közel 8,5 milliárd forint támogatást tudhat magáénak a hazai borágazat.

\subsection{Borászok 12 pontja - Winemakers 12 Points}

2009 decemberében elkészítették a Borászok 12 pontját, mely azokat a célokat és alapelveket tartalmazza, mely megvalósításával a magyar borágazat érdekei érvényesíthetők. A kiáltvány a következőket tartalmazza [8]:

1. A szőlészet és borászat kiemelt mezőgazdasági ágazatként történő kezelése.

2. A bor jövedéki- és termékdíj szabályozás jelenlegi formájának megszüntetése.

3. A hegyközségi törvény és rendtartások újragondolása. 4. A kutatás és az oktatás megújítása.

5. A mezőgazdasági alkalmi munkavállalás egyszerūsítése.

6. A forgalomba hozatali engedélyezés európai normákhoz igazítása.

7. A támogatások igénylésének egyszerúsítése.

8. Kormányzati tanácsadó bortestület létrehozása.

9. Országos bormarketing kialakítása az árubor termelők felügyeletével.

10. Szőlő- és bortermelő települések építészetének különleges felügyelete.

11. Saját készítésű párlat és pezsgő forgalmazási lehetőségének egyszerúsítése.

12. A borfogyasztás és gépjárművezetés viszonyának ésszerű szabályozása.

\section{ANYAg ÉS MÓDSZER - MATERIALS AND METHODS}

A szekunder vizsgálatok a nemzetközi és a hazai borászatra jellemző adatok, valamint különféle hazai és külföldi szakirodalmak megismerésére és feldolgozására irányultak, kiemelt figyelmet fordítva a bortermelés, a borvásárlás, a borfogyasztás tendenciáinak, valamint a bormarketing tevékenység alakulásának vizsgálatára. A kutatási téma részletes megismerése céljából adatgyüjtést végeztem a marketingkutatás elismert módszerének - a szekunder kutatás - alkalmazásával. A szekunder jellegű kutatás (íróasztali vagy másodlagos) a mások által összegyüjtött és közzétett, eredetileg más kutatási célt szolgáló adatok megszerzése és új szempontok szerinti feldolgozása [3].

\section{EREDMÉNYEK - RESUltS}

\subsection{Bortermelés és borfogyasztás hazánkban - Wine Production and Consumption in Hungary}

A KSH grafikonjának adataiból kiszámolható, hogy a feltüntetett 2002-2013. közötti időszakban az éves átlagtermés cca. 342 millió liter bor volt évente (1. ábra). Sajnálatos azonban az a tény, hogy míg közel 40 évvel ezelőtt 184 ooo hektár szőlőn gazdálkodtak a magyarok, addig tavaly már csak 60 ooo hektáron, ennek megfelelően a feldolgozott bor mennyisége is csökkent, 1976-ban 510 millió litert, míg tavaly 224 millió litert termeltek. A drasztikus csökkenés egyik oka, hogy 2005-től jelentős uniós támogatásra pályázhatott az, aki kivágta az ültetvé- 
nyét. Ennek következménye, hogy az elmúlt 9 évben több, mint 10 ezer hektár szőlőültetvény szűnt meg. A bortermelés hanyatlásában nem a fogyasztás csökkenése játszik közre. Kevesebb bort iszunk, de nem kizárólag azok roszszabb minősége miatt. Közrejátszik még a klímaváltozás is, illetve a kevesebb költés a gazdasági válság miatt.

A KSH adatai szerint 2007 óta az egy före jutó borfogyasztás folyamatosan csökken (2. ábra). A 2012-es évben fogyasztott mennyiség azonban majdnem egy literrel kevesebb, mint az azt megelőző öt évi átlag. A 2012-es évben a szőlőtermelés - a 2011-es évben bekövetkezett terméskiesést követően - 50 \%-kal nőtt, mégsem érte el még mindig a 2010-es mutatókat. A KSH statisztikái szerint mind a bortermelés, mind a borfogyasztás csökkenő

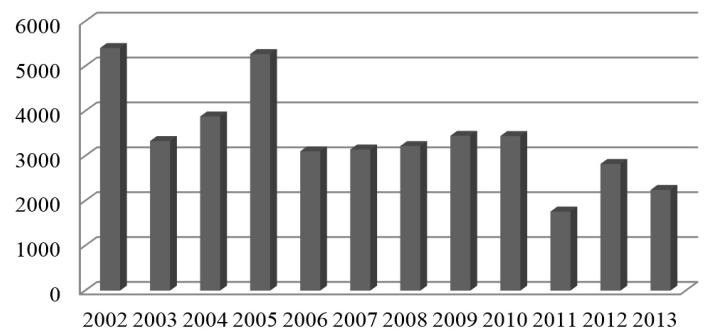

1. ÁBRA

Bortermelés Magyarországon, 1000 hektoliter

Wine production in Hungary, 1000 hektoliter Forrás (Source): KSH, 2014

\section{KöVETKEZTETÉSEK ÉS JAVASLATOK - CONCLUSIONS AND PROPOSALS}

A lényeg, hogy kevesebbet költünk borra, illetve alkoholra. Rosszabb minőségü lett az általában keresett közepes minőségü (kb. 1400 Ft-os) borok minősége és ezért veszünk belőlük kevesebbet. 2011-ben nemcsak a borok minősége, a mennyisége is alacsony volt, ahogy az látható a grafikonból. 2012-re azonban a mennyiségi helyzet nem nagyon állt helyre, a csökkenésért ugyanis nemcsak a hideg és a fagy, hanem a meleg is okolható. A borpiacok küzdelmét a klimatikus körülmények változása szintén hátráltatja több szempontból is: minél melegebb van, annál gyorsabban érik a szőlő, amitől a közkedvelt fehérborok oxidációja felgyorsul, így romlik a borok minősége. Azonban a magas hőmérséklettől nő az alkoholfok is.

\section{5. ÖSSZEFOGLALÁS - SUMMARY}

A bor egy olyan nemes ital, amelyet egyes nemzetek büszkén fogyasztanak és készítenek.

A szőlőművelésnek és borkészítésnek hagyományai vannak. A nemzetközi borpiacon a hagyományos bortermelő országok mellett megjelentek a „hódító” bornemzetek. A magyar borászat nincs rossz helyzetben. Kiváló szakembereink vannak és a természeti adottságaink is megfelelőek. A borfogyasztás szokásainak vizsgálatából kiderült, hogy itthon az egyik legkedveltebb alkohol a bor, amelyet a magyarok kiváltképpen ünnepekkor fogyaszta- tendenciát mutat. 2011-ben már csak 176 millió liter bort termelt hazánk, míg az évi fogyasztás egy átlagember esetében 5,7 liter/év volt. A borfogyasztási megfigyelések a 2002 és 2012 közötti időszakot ölelik fel: míg a vizsgált időintervallum kezdeti pontján közel 8 liter bort ivott meg egy átlagos itthoni fogyasztó, míg ez a szám 10 év elteltével 4,9 liter/före csökkent.

A Borászportál által 2011-ben végzett online kutatás, melyben a borfogyasztási és borvásárlási szokásokra volt kíváncsi, azt mutatta, hogy az 500-100o Ft-os és az 10002000 Ft-os árkategóriában található borok a legkeresettebbek a fogyasztók által. Vagyis, átlagosan csak 1400 Ft-ot költünk borra.

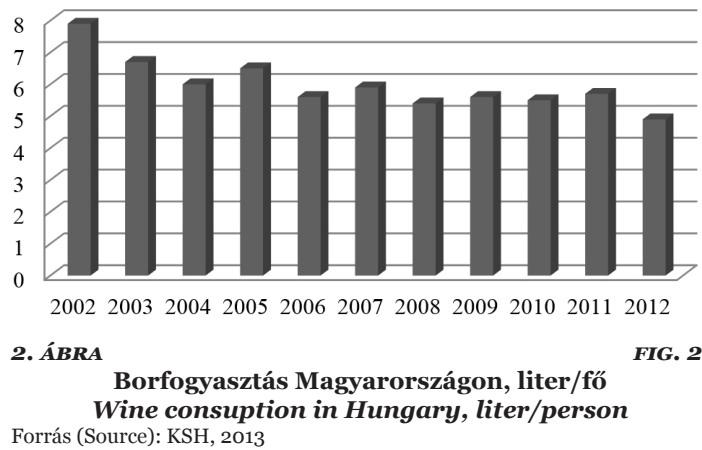

nak szívesen. Míg a hazai borfogyasztás évról évre csökken, a fiatalok körében mégis divat lett érteni a borokhoz. A magyar borkultúra szintje viszonylag alacsony, bár fejlődési pályán van. Szükséges tehát a borkultúrát javító szerveződések támogatása, kitalálása.

\section{IRODALOMJEGYZÉK - REFERENCES}

[1] Gaál B. - Párdányi M.: Bormarketing. Mezőgazda Kiadó. Budapest, 2007.

[2] Hajdu I.: Bormarketing. Mezőgazda Kiadó, Budapest, 2004.

[3] Hajdu I.: Borpiac. Mezőgazda Kiadó, Budapest, 2006.

[4] Kiss K. Á.: Magyar bormarketing és borfogyasztás. In: Agrártudományi Közlemények, Acta Agraria Debreceniensis. 2012. 52

[5] Kotler, P.: Marketing menedzsment. KJK-Kerszöv Jogi és Üzleti Kiadó Kft., Budapest, 2002.

[6] Lehota J. - Fehér J.: Borexport-marketing. Szent István Egyetem Gödöllő. Marketing Intézet- EU Leonardo Projekt. 2007.

[7] Tóth S. - Rohály G.: Terra benedicta - Áldott föld, AKÓ Kiadó, Budapest, 2004.

[8] http://www.boraszok12pontja.com (Letöltés dátuma: 2014. szept. 13.) 


\section{JEGYZETEK * NOTES}

